CAHIER DE RECHERCHE \#1302E

Département de science économique

Faculté des sciences sociales

Université d'Ottawa
WORKING PAPER \#1302E

Department of Economics

Faculty of Social Sciences

University of Ottawa

\title{
Carbon Taxes, Agricultural Competitiveness and Trade*
}

\author{
Nicholas Rivers $^{\dagger}$ and Brandon Schaufele ${ }^{\ddagger}$
}

August 2013

\footnotetext{
${ }^{*}$ Funding for this project was provided by the Pacific Institute for Climate Solutions. The authors acknowledge the excellent research assistance of Linda Li and Noemie Schmiedel.

${ }^{\dagger}$ Graduate School for Public and International Affairs, University of Ottawa, 120 University, Ottawa, Ontario, Canada, K1N 6N5; Email: nicholas.rivers@uottawa.ca.

${ }^{\ddagger}$ Department of Economics and Institute of the Environment, University of Ottawa, 120 University, Ottawa Ontario, Canada, K1n 6N5; E-mail: brandon.schaufele@uottawa.ca.
} 


\begin{abstract}
This study evaluates the implications of an actual carbon tax on the international competitiveness of the agricultural sector. Applying uniformly to all fossil fuels combusted within its borders, the province of British Columbia unilaterally introduced a carbon tax on July 1, 2008. Using commodity-specific trade flows and exploiting cross-provincial and inter-temporal variation, we find little evidence that the implementation of the carbon tax is associated with any meaningful effects on agricultural exports despite the sector being singled out as "at risk" by the provincial government. Allowing for heterogeneous responses by commodity, some statistically insignificant negative effects are shown for specific exports. Discussion of potential policy remedies to address the potential impacts of the tax on firm profitability and international competitiveness is also included.
\end{abstract}

Key words: Agricultural trade; British Columbia; carbon tax; competitiveness; unilateral climate policy.

JEL Classification: H23, Q17, Q5.

\title{
Résumé
}

Cette étude évalue les implications d'une taxe carbone sur la compétitivité internationale du secteur agricole. Appliquer uniformément à tous les combustibles fossiles brûlés à l'intérieur de ses frontières, la province de la Colombie-Britannique a instauré unilatéralement une taxe carbone le $1^{\text {er }}$ Juillet 2008. Utiliser les flux commerciaux des produits spécifiques et exploiter variation inter-provincial et intertemporelle, nous trouvons peu de preuves que la mise en œuvre de la taxe carbone est associée à des effets significatifs sur les exportations agricoles malgré le secteur étant identifiée comme «à risque» par le gouvernement provincial. En tenant compte des réponses hétérogènes par produit, des effets négatifs statistiquement significatifs sont indiqués pour les exportations spécifiques. Discussion sur les remèdes possibles des politiques pour faire face aux impacts potentiels de la taxe sur la rentabilité des entreprises et la compétitivité internationale est également incluse.

Mots clés: Agricole, Colombie-Britannique, la taxe carbone, la compétitivité, la politique climatique unilatérale.

Classification JEL: H23, Q17, Q5. 


\section{Introduction}

British Columbia (BC) introduced a carbon tax on all fossil fuels consumed in the province on July 1, 2008. Carbon taxes are considered to be among the most efficient marketbased instruments to reduce greenhouse gas emissions: they raise revenue which can be used for productive purposes such as reducing other tax distortions (Goulder, Parry, \& Burtraw, 1997), provide strong incentives for technological innovation (Fischer \& Newell, 2008) and have small transaction costs (Stavins R. , 1995). Further, BC’s carbon tax combines a unique set of policy characteristics, placing it among the best designed environmental policies in the world: i) the carbon tax is coupled with targeted rebates to low-income and remote households, alleviating concerns over the regressivity; ii) revenue from the carbon tax is used to reduce rates of corporate and personal income taxation, a design admits the possibility of a "double dividend" (i.e., a reduction in greenhouse gas emissions as well as an increase in economic output) (Goulder, 1995); and, iii) finally, the tax applies an identical rate per tonne carbon dioxide equivalent $\left(\mathrm{tCO}_{2} \mathrm{e}\right)$ to all emitters, invoking the equimarginal principle and yielding greenhouse gas reductions at the lowest social cost. Yet, while the tax is well-designed, concerns remain over its implementation - namely, BC’s carbon tax was enacted unilaterally and applies only to $\mathrm{BC}$ residents. In particular, the BC government stressed that the agricultural sector as expressly susceptible to international pressures due to this independent legislation. This paper examines the trade implications of BC's unilateral implementation of a carbon tax on the agricultural sector.

Unilateral implementation raises qualms over adverse effects, especially in the presence of trade. Differential environmental regulations might cause firms operating in BC to move to another (un-taxed) jurisdiction. A large literature tests whether such “pollution havens” have formed in response to differential environmental policies. Early studies report that the effects of 
environmental regulation on net exports, overall trade flows and plant-location decisions are small, statistically insignificant or not robust to model specification (Jaffe A. B., Peterson, Portney, \& Stavins, 1995). Recent empirical work, employing methods to deal with unobserved heterogeneity and simultaneity, finds that "after controlling for other factors affecting trade and investment flows, more stringent environmental policy acts as a deterrent to dirty-good production” (Copeland \& Taylor, 2004). If unilateral environmental regulations do cause some firms to move production to other jurisdictions, legitimate concerns over emissions leakage can be raised. Leakage implies that a share of the emission reductions in the regulated jurisdiction is re-emitted in other jurisdictions. These trade effects limit the effectiveness of the tax at reducing greenhouse gases.

Pollution havens are also linked to competitiveness. Competitiveness is not a precisely defined concept, but reflects an amalgam of concerns related to losses in employment, profitability and international trade (exports). Difficulties are greatest in sectors with relatively high greenhouse gas intensity, those which face international trade pressure and those which receive little benefit from the revenue-recycling mechanisms that accompanied the tax. Agricultural production is frequently perceived as a fossil fuel intensive sector that faces stiff international competition. As such, it may be particularly adversely affected by the carbon tax. The BC Government appeared to acknowledge the agricultural sector's concerns over the unfavourable competitiveness implications of the carbon tax - in its 2012 budget speech, the BC Government looked to "examine the tax's impact — both positive and negative — on every economic sector” (BC Budget Speech, 2012, p. 15). Of note, government stated its intention to "pay particular attention to agriculture, recognizing its critical importance to our future” (pg. 15). Singling out the agricultural sector as an "at-risk" industry is likely the result of the pre-budget 
consultation process. In particular, industry representatives claimed that the tax was “devastating” agricultural producers and that "it is one of the hardest-hit industries when it comes to the carbon tax" (BC Budget Consultation, 2012). They also claimed that "There is no offset for [agricultural producers], so no matter what you give back in taxes, it doesn't matter” (BC Budget Consultation, 2012).

This paper empirically evaluates the consequences of the BC carbon tax on leakage and competitiveness of the agricultural sector. We exploit a commodity-specific panel data set reflecting trade in all provinces between 1990 and 2011. After controlling for geography and time invariant factors in addition to other covariates (e.g., weather), we find little evidence that the implementation of the $\mathrm{BC}$ carbon tax is associated with a decline in exports from the agricultural sector. The tax does not appear to have any meaningful effects on the international competitiveness of BC's agricultural sector. In fact, in our preferred model a carbon tax of $\$ 20 / \mathrm{tCO}_{2} \mathrm{e}$ is associated with an increase in gross exports of 1.5 percent. Once we investigate crop-specific heterogeneity, we do find a small, statistically insignificant effect for vegetable, live tree and other floriculture exports. These findings suggest that large exemptions granted to the agricultural sector are inefficient and unnecessary. Nonetheless, lingering nervousness may persist. Consequently, we discuss alternative rebating schemes which would alleviate competitiveness pressures on the sector at a lower efficiency cost than sectoral exemptions.

The remainder of the paper is structured as follows. Section 2 describes the BC carbon tax is described, with a particular focus on the use of revenues raised as a result of the tax. Section 3 presents the canonical international trade theoretical model. This framework predicts the differential impact of the introduction of a carbon tax on sectors with differing carbon intensity and exposure to international markets. Section 4 contains our empirical analysis. 
Section 5 reviews mechanisms that could be used to mitigate the negative impacts of a carbon tax on international trade, competitiveness, and leakage. Section 6 concludes.

\section{Overview of the BC Carbon Tax}

The introduction of the BC carbon tax surprised the majority of province's residents (Harrison, 2012). Announced by the province’s Finance Minister in her February 2008 budget speech, the tax was implemented very quickly. By July 1st, 2008, BC became the first jurisdiction in North America to tax fossil fuels based on carbon content at an equivalent level. ${ }^{1}$ Only during the second half of 2007 did the government began to hint that environmental pricing was possible. Even then, there was no public acknowledgement that carbon taxes were a prospective policy option until a speech late in October 2007. Early reactions to the carbon tax were positive and polls showed that a majority of voters supported the policy (Harrison, 2012). Residents appear to have understood the impetus for the tax and accepted that it was a welldesigned policy. The most notable demonstration of popular support was when the Liberal Party of British Columbia, the political party that introduced the tax, was granted a third consecutive majority government in a post-carbon tax election.

The carbon tax is comprehensively applied to all greenhouse gas emissions generated from burning fossil fuels, with the effective tax rate for each type of fuel determined based on carbon content. The tax rate started at $\$ 10$ per tonne $\mathrm{CO}_{2} \mathrm{e}$ in July 2008, and increased by $\$ 5$ per tonne every year to achieve $\$ 30 / \mathrm{tCO}_{2} \mathrm{e}$ by July 2012 (BC Ministry of Finance, 2011). At $\$ 10 / \mathrm{tCO}_{2} \mathrm{e}$ the tax represents an increase of $2.69 \mathrm{q} /$ litre of diesel and at $\$ 30 / \mathrm{tCO}_{2} \mathrm{e}$ this increase raises to $7.67 \$ /$ litre. Increasing the level of the tax through time allows consumers to gradually

\footnotetext{
${ }^{1}$ The city of Boulder, CO, and the province of Quebec implemented carbon taxes in 2007, but at much lower levels that in British Columbia.
} 
adjust their fuel usage and change their habits. This feature of the policy also facilitates investment planning by firms and individuals, since a fixed 5-year schedule of tax increases was legislatively mandated. Initially, the BC carbon tax was implemented with no exemptions granted to any groups or industries.

Generating an estimated income of \$960 million for 2011-2012 (BC Ministry of Finance, 2012), the BC carbon tax was introduced as revenue neutral. Revenue-neutrality entails returning all carbon tax revenues to residents via adjustments to personal and corporate taxes as well as via lump-sum transfers. The generated income lowered each of personal, corporate and small business income tax rates. It also reduced school property taxes for land classified as "farm”, gave industries property tax credits and provided transfers to lower-income families and northern and rural homeowners (BC Ministry of Finance (d) 2012). The BC government, for example, lowered the rate of tax on the bottom two personal income tax brackets and introduced a series of lump-sum transfers to protect low-income and rural households. Low income households receive quarterly rebates, which, for a family of four, equal approximately $\$ 300$ per year and beginning in 2011 northern and rural homeowners received a further benefit of up to $\$ 200$.

Despite these tax shifts, there is a perception that the carbon tax is reducing the $\mathrm{BC}$ agricultural sector's competitiveness and profitability while dramatically increasing their energy costs. The carbon tax was introduced during an uncertain period for producers. A high Canadian dollar, volatile commodity prices and lack of trade protection has been called a "perfect storm" for the farming community. The coincident timing of these challenges with the introduction of the carbon tax has led farmers to target and blame the carbon tax for the difficulties in the sector (BC Budget Consultation, 2012). 
A major reason for the agricultural sector's dislike of the carbon tax is the perceived difficulties in adapting to the new tax by decreasing fuel-use in the short-run. Heating greenhouses and harvesting crops with machinery are essential to the proper functioning of farms. An increase in the price of fuels leads to an increase in energy costs that could lead to adverse results for the industry: decreasing profits, reduction of planted acres, a decline in net exports or even farms leaving the BC market altogether. As a result of these perceived challenges, the government granted BC's high-tech greenhouse vegetable and horticulture growers a one-time, $\$ 7.6$ million reprieve from the carbon tax relief, "allowing producers to focus on maintaining their competitive edge” (BC Ministry of Agriculture, 2012). The objective of this exemption is to enable BC growers to better compete with producers in the USA and Mexico. Yet, still unknown are the magnitude of the adverse impacts incurred by the province's agricultural sector. Further, exempting "at risk” industries may not be the most efficient mechanism for protecting competitiveness. The objective of this study is to quantify commodity-specific trade impacts attributable to the carbon tax.

\section{Theoretical Framework: Carbon Taxes and International Trade in Agriculture}

The introduction of unilateral environmental regulations increases domestic costs of producing pollution-intensive goods and may induce comparatively disadvantaged dirty good production to shift from a regulated jurisdiction (BC) to an unregulated jurisdiction. This core prediction comes from the canonical Hecksher-Ohlin model of comparative advantage (correspondingly, activities that are "clean” are projected to shift to the regulated jurisdiction). This is illustrated in Figure 1 with a five panel graphical model describing an economy that uses 
two factors of production - labour and fossil fuels - to produce two distinct goods - A and B. ${ }^{2}$ Each good is assumed to be homogeneous, traded internationally and consumed by both countries. ${ }^{3}$ Production of good $\mathrm{A}$ is assumed to be relatively energy-intensive while production of good B is labour-intensive.

Panel I of Figure 1 captures the technology for production of good A. Red isoquants represent the quantities of the two inputs required for a given level of output. (Curvature of the isoquants reflects the familiar assumptions about declining marginal products of factor inputs.) The isoquant for B production is superimposed on the original figure in Panel II, with the reference for good B production having an origin in the northeast of the figure, and the origin for good A production in the southwest of the figure. In this figure, units are chosen such that the total available amount of each factor in the economy is normalized to 100; when a unit of an input factor is used in the production of one good, it is no longer available for the production of the other good. The blue line in the figure connects all points where the marginal rate of technical substitution between the two factors of production for each of the two goods is equal. Each of these points is an efficient production point; when the economy is not at one of these points, productive efficiency could be improved by reallocating resources to achieve this efficient allocation. Given a competitive economy, the equality of marginal rate of technical substitution for the two goods-producing sectors will be reflected in the relative prices of the two inputs.

Panel III transposes the information from Panel II into A-B space, and depicts the production possibility frontier for the economy (which reflects points along the solid blue line in

\footnotetext{
${ }^{2} \mathrm{~A}$ formal mathematical model is available from the authors by request. We believed that the graphical depiction provided more intuition, so we omitted it from the text.

${ }^{3}$ These assumptions underlie the simple Hecksher-Ohlin model that is widely used for simple theoretical analysis of international trade.
} 
Panel II). Superimposed on this figure is a red line depicting relative world prices of the two goods; given a competitive economy, the economy produces at point $x$ in the figure.

With this basic framework, it is possible to depict the consequences of BC's unilateral imposition of a carbon tax. Consider now a reduction in the domestic availability of fossil fuels (caused by the carbon tax). Panel IV illustrates the impact of the carbon tax on the allocation of factors of production. When consumption of fossil fuels is reduced following the introduction of the carbon tax, a new set of efficient allocations of productive factors becomes available. These are represented by the dashed blue line in Panel IV. Following the same logic as above, the production possibility curve shifts inwards to the dashed line in Panel V. Because production of good A is fossil fuel-intensive, a reduction in the use of fossil fuels asymmetrically shifts the production possibilities frontier inwards, such that the maximum production of good A falls more than that of good B. At fixed world prices, the production of the two goods moves to the point labelled $y$ in the figure. Production of good A - the energy-intensive good - has declined, while production of good B - the labour-intensive good - has increased in response to the carbon $\operatorname{tax}^{4}$

Panel V also shows the community indifference curve in green. At world prices given by the red line, utility is maximized at point $z$ prior to the introduction of the carbon tax, and at point $w$ after the introduction of the carbon tax. With production and consumption identified, the impact of the policy on exports can be determined. Initially, production of commodity A - the energy-intensive commodity - is much greater than consumption, such that commodity A is exported. The horizontal distance between $z$ and $x$ gives exports in the reference case, and this quantity is given the label $X_{0}$ in the figure. After the introduction of the carbon tax, production

\footnotetext{
${ }^{4}$ According to the Rybczynski Theorem, which uses a similar set-up, a reduction in an endowment more than proportionately reduces output of the good that is intensive in the use of that factor.
} 
falls substantially while consumption falls only slightly: exports of commodity A have therefore fallen. The horizontal distance between $w$ and $y$ gives exports under the carbon tax; these are labelled as $X_{1}$ in the figure. ${ }^{5}$ Since consumption of the energy-intensive commodity is not significantly changed, but domestic production has fallen, it must be the case that production has shifted to other countries: those with relatively weaker environmental regulations. This is the leakage/competitiveness effect that concerns policy makers.

In the following, we test two predictions that arise from this model in the context of the agricultural sector. First, we examine whether agriculture is a pollution-intensive sector in British Columbia and thus unduly impacted by the carbon tax. Second, we empirically investigate whether agricultural exports have been affected by the introduction of British Columbia's carbon tax.

\section{Empirical Analysis}

This section proceeds via several steps. First, we examine whether BC's agricultural sector can be considered carbon-intensive according to conventional metrics. Next, we estimate a series of econometric equations focusing on the effect of the carbon tax on gross and net exports. Finally, we discuss several rationalizations for our results.

\subsection{Is British Columbia's agricultural sector pollution-intensive?}

The theoretical model suggests that a pollution tax will cause a contraction in production and exports from the relatively pollution-intensive sector. While unambiguous predictions can be derived from this two input framework, it is more challenging to determine the fossil-fuel intensive industries when there are multiple sectors producing a range of outputs. Further, some goods are produced exclusively for domestic markets, while others are exported and, while the

\footnotetext{
${ }^{5}$ In contrast, commodity B is imported, and net imports of commodity B fall as a result of the carbon tax.
} 
theory is based on homogeneous goods, in reality, consumers might have preferences over the origin of goods and goods may be distinguished by brand or other characteristics, such that goods cannot be considered homogeneous (e.g., Carter, Krissoff and Zwane, 2006). As such, it is useful to consider the structure of BC's economy to generate a first-order approximation of which sectors are most likely to face declines in comparative advantage following the introduction of a unilateral carbon tax.

Data on fossil fuel usage by sector and on trade by commodity are available from Statistics Canada's System of National Accounts. Denote matrix $\mathbf{U}$ as the $i x j$ use matrix (use of commodities $i$ by sector $j$ ), matrix $\mathbf{M}$ as the $i x j$ make matrix (output of commodities $i$ by sector $j$ ), and matrix $\mathbf{F}$ as the $i x f$ final demand matrix (with $f$ final demand categories). ${ }^{6}$ Total domestic output is given by $\mathbf{q}=\mathbf{M} \mathbf{i}$, and total domestic use by industry is given by $\mathbf{g}=\mathbf{U}^{\prime} \mathbf{i}$. Define the input coefficient matrix $\mathbf{B}$ as the commodity proportions required to produce a single unit of output in each industry, such that $\mathbf{B}=\mathbf{U} \hat{\mathbf{g}}^{-1}$. Similarly, define the market share matrix $\mathbf{D}$ as the market share of each sector in the production of each commodity, such that $\mathbf{D}=\mathbf{M} \hat{\mathbf{q}}^{-1}$. Finally, generate the $i x i$ technical coefficient matrix $\mathbf{A}$, which defines the intermediate input requirements for producing each commodity as $\mathbf{A}=\mathbf{B D}$. From matrices $\mathbf{A}$ and $\mathbf{F}$, it is possible to obtain the cost share of fossil fuel inputs required to produce a unit of each commodity, as well as the trade intensity of each commodity.

Figure 2 plots the trade intensity for each commodity in Statistics Canada's S-Level database against the cost share of fossil fuel in its production (national accounts data are available at different levels of aggregation, with the S-Level the only level of aggregation publicly available for provincial data). These two measures are directly relevant to the

\footnotetext{
${ }^{6}$ Throughout, boldface text denotes a matrix or vector, the prime symbol denotes a transpose, $I$ is the identity matrix, $\mathbf{i}$ is a column vector of ones, and a circumflex denotes a diagonal matrix.
} 
theoretical model presented above. For instance, commodities that are not highly traded are unlikely to experience large changes in imports or exports as a result of the imposition of unilateral environmental policy. Similarly, sectors that do not consume substantial amounts of fossil fuels are unlikely to experience large cost increases due to the carbon tax, and thus are likely not to experience major changes in their ability to compete with foreign producers. In contrast, commodities that use a high proportion of fossil fuels in production and which are highly traded are those where imports may supplant domestic production following imposition of a carbon tax. As a result, energy-intensive and trade-exposed thresholds have been widely used in policy formation. For example the proposed Waxman-Markey cap and trade bill, a prominent piece of US legislation, defined a sector as energy-intensive and trade-exposed if energy expenditures represented more than 5 percent of total costs, and if trade intensity was greater than 15 percent. $^{7}$

Figure 2 demonstrates that most commodities produced in British Columbia have both low trade intensity and low fossil fuel intensity. ${ }^{8}$ This reflects the fact that services, which dominate the economy of BC (and other provinces), are typically not highly traded and are not energy-intensive. Compared to the other highly-traded goods produced in BC (because of the natural break in the data that appears at a trade intensity of around 0.5 , we treat goods with trade intensity greater than 0.5 as "highly-traded”), agricultural goods do not stand out as particularly fossil fuel intensive. Production of fruit, vegetables, and other food products and feeds, as well as production of meat, fish, and dairy products, has a cost share of about 0.04 for fossil fuels (i.e., $4 \%$ of total costs are for fossil fuels). This is larger than the cost share of fossil fuels for

\footnotetext{
${ }^{7}$ Trade intensity, as defined in the Waxman-Markey bill and adopted here, is (imports+exports)/(imports+domestic output). Note that trade intensity for the US as a whole is much lower in general than for a Canadian province because of differences in size of BC vs. US.

${ }^{8}$ Unfortunately, the high degree of data aggregation in the Statistics Canada S-Level data can obscure important outliers in the data.
} 
services, but lower than or equal to the cost share of fossil fuels in many manufactured goods. Likewise, the trade intensity of about 0.6 is greater than that of domestically-oriented commodities (services), but less than that of internationally traded manufacturing commodities.

As a result, it is not obvious that agriculture should be considered a sector that should be lumped into the highly-traded and fossil-fuel intensive category. Still, energy-intensive and tradeexposed measures are arbitrary and it is not obvious that commodity-specific trade flows were not adversely impacted.

\subsection{Estimating the impact of the carbon tax on commodity-specific trade}

A major review of econometric studies conducted in the 1990s concluded that, "there is relatively little evidence to support the hypothesis that environmental regulations have had a large impact on competitiveness” (Jaffe A. B., Peterson, Portney, \& Stavins, 1995). Recently however, several deficiencies have been identified in the early analysis. After correcting for these issues, environmental regulation has been shown to have a modest effect on trade (Levinson \& Taylor, 2008; Kellenberg, 2009). For example, Levinson and Taylor (2008) estimate that a doubling in pollution abatement expenditures in response to more stringent environmental regulation in the US over a one-decade period between 1977 and 1986 led to an increase in net imports of pollution-intensive goods from Mexico of around 40 percent. This prospective negative relationship between exports and environmental regulation is an important consideration for policymakers for two reasons. First, an out-migration of polluting industries from a regulated jurisdiction to an unregulated jurisdiction could work against the policy that caused the migration in the first place since emissions in the unregulated jurisdiction would no longer be affected by the policy. Often estimates of the "leakage" associated with changing trade patterns due to environmental policies suggest that leakage is unavoidable, but unlikely to 
swamp the effect of the policy (Felder \& Rutherford, 1993). Nonetheless, emissions leakage is an important concern for policymakers. Second, if a unilateral environmental policy causes a shift of economic activity to other countries, policymakers are rightly concerned about the loss in domestic welfare associated with the loss in industry competitiveness.

In an effort to examine the impact of the BC carbon tax on agricultural competitiveness, we construct a dataset covering international trade and output in agricultural commodities in all Canadian provinces and estimate whether the introduction of the BC carbon tax has been associated with a measurable change in trade patterns. To do so, we build on the framework introduced in Levinson and Taylor (2008). Specifically, we start with the following equation:

$$
X_{i j t}=\beta_{0}+\beta_{1} s_{i j t}+\beta_{2} c_{i j t}+\beta_{3} c_{i j t}^{X}+\beta_{4} \tau_{i j t}+\beta_{5} \tau_{i j t}^{X}+\varepsilon_{i j t}
$$

where $X_{i j t}$ is exports of good $i$ from region $j$ (expressed as a fraction of production in region $j$ ), $s_{i j t}$ is region $j$ 's share of world spending on good $i, c_{i j t}$ is a unit cost function for production of good $i$ in region $j, \tau_{i j t}$ is the environmental policy in region $j$ for good $i$, and the superscript $X$ indicates a foreign variable.

We do not however observe home costs, foreign costs, or foreign environmental policies. As in Levinson and Taylor, we accommodate these unobservables with a set of interacted time and region fixed effects to control for factors that would otherwise confound our analysis. We specify the following model:

$$
X_{i j t}=a \tau_{j t}+b_{j}+d_{i t}+f\left(t_{j t}, p_{j t}\right)+\varepsilon_{i j t}
$$

where the good-region fixed effect $b_{j}$ captures comparative advantage. Comparative advantage refers to slowly-moving stocks such as land quality, climate, human and physical capital. Thus, this time-invariant commodity-region factor parameter captures average differences between 
home and foreign unit costs that govern comparative advantage. The commodity-time dummy $d_{i t}$ controls for commodity-specific changes over time that similarly affect all Canadian provinces. For example, national trade policy, exchange rate fluctuations, tariffs and the mean ratio of foreign to domestic costs of production are captured by this fixed effect. These fixed effects enable us to net out factors which drive common home-foreign jurisdiction cost differentials. Remaining variation comes from province-commodity-year shocks. The most prominent of these is prevailing weather. As such, we incorporate a polynomial of weather terms $\left(f\left(t_{j t}, p_{j t}\right)\right)$ which includes actual and squared spring and summer temperature indices (given by $t_{j t}$ ) as well as actual and squared spring and summer precipitation indices (given by $p_{j t}$ ). Finally, the error terms, $\varepsilon_{i j t}$, are assumed to be uncorrelated with the primary variable of interest, the carbon tax $\left(\tau_{j t}\right)$, and pick up changes in foreign environmental policies, classical measurement error in addition to time-variant changes in the ratio of home and foreign commodity-specific unit costs. Unbiased estimates for the carbon tax coefficient rely on lack of correlation between these omitted variables and the independent variables in the model.

Our coefficient of interest is $a$. This parameter shows the impact of the tax on agricultural exports. Unlike Levinson and Taylor (2008) and many other contributors to the literature on international trade and the environment, we do not employ a proxy for environmental regulatory stringency, but instead measure stringency directly with the carbon tax. ${ }^{9}$ This exogenous measure of regulatory stringency simplifies our estimation significantly compared to other contributions as it is plausibly unconfounded with the error term and is precise. Finally, we conduct a sequence of robustness checks on our results to test whether

\footnotetext{
${ }^{9}$ The typical measure of regulatory stringency in this literature is pollution abatement cost per unit of value added. Since industry structure can change in response to regulatory stringency, this proxy measure is endogenous, creating difficulties with estimation.
} 
changes in the sample size or in the estimation equation result in changes in the economic or statistical significance of our coefficients.

\subsection{Data}

We collect annual data on farm receipts by agricultural commodity and by province for 1970-2011 from Statistics Canada’s Table 002-0001 and annual data on provincial imports and exports by agricultural commodity from 1990-2011 from Industry Canada’s Trade Data on-line. The commodity classification used by Statistics Canada and Industry Canada is slightly different, so the two data sets require manual merging. Table A1 in Appendix A documents the commodity concordance table that we assembled to conduct the analysis. ${ }^{10}$ In addition to data on production, imports, and exports, data on weather is sourced from Environment Canada’s Climate Trends and Variations Bulletins, which reports regional precipitation and temperature anomalies on a seasonal basis. Although the regions used by Environment Canada closely approximate provincial boundaries, the match is not exact. The concordance between Environment Canada regions and provinces used in the analysis is reported in Appendix A Table A2. ${ }^{11}$

\subsection{Results for gross exports}

Table 1 shows the main results of our analysis. In the first column, the coefficient on the carbon tax variable is estimated at 0.335 , which suggests that every one dollar increase in the carbon tax is associated with a 0.3 percent increase in gross exports of agricultural commodities from British Columbia. The coefficient is precisely identified (significant at a 5 percent level) with clustered standard errors presented I parentheses (clustered on provinces). At $\$ 10 / t \mathrm{CO}_{2}$,

\footnotetext{
${ }^{10}$ Supply-managed commodities (poultry, dairy, etc.) are not included in the analysis, since producers in these sectors face different incentives compared to other sectors.

${ }^{11}$ The regions adopted by Environment Canada are reported in seasonal bulletins: http://www.ec.gc.ca/adsccmda/default.asp?lang=En\&n=4CC724DA-1\#a4.
} 
the value of the carbon tax in 2008, our model predicts that the value of agricultural exports is about 3.3 percent higher than in the counterfactual where the carbon tax is not employed. At $\$ 30 / \mathrm{CO}_{2}$, the value of the carbon tax in 2012, the model predicts that the value of agricultural exports is about 10 percent higher than had the carbon tax not been in place (note that the model does not include data for the year 2012, so this is an out-of-sample prediction).

The second column of the table is our preferred model. It repeats the analysis of column 1 with commodities marketed by a single-desk marketing board excluded. These commodities in our original sample include wheat, barley, and oats. ${ }^{12}$ The coefficient estimate in this case drops to 0.069 , and we are unable to reject the possibility that the coefficient is actually zero. Thus the finding that the carbon tax is associated with increased gross exports is due primarily to singledesk marketed cereal commodities and, as such, may be due to idiosyncratic characteristics associated with those particular commodities.

In the third column of the table, we also include the Quebec carbon tax (which is roughly $\$ 3 / \mathrm{CO}_{2}$, and was introduced in late 2007). Including this separately allows us to test the robustness of our findings to an alternative sample. As the estimate in column 3 reports, the coefficient maintains the same magnitude as in the first column and is statistically different from zero. Finally, the fourth column of the table employs a log-linear functional form, rather than a linear functional form as in the other columns. Employing this functional form can help to resolve potential problems associated with heteroscedasticity and can also effectively address problems associated with outliers in the data. ${ }^{13}$ The log-linear model gives results that are

\footnotetext{
${ }^{12}$ Wheat, barley and oats are relatively unimportant to the $\mathrm{BC}$ agricultural sector. Along the same lines, commodities that are supply managed were excluded from the analysis completely.

${ }^{13}$ The coefficient estimate and standard error in the table are transformed to be comparable to other columns. In particular, the estimate from the log-linear model is multiplied by the mean value of the dependent variable in the sample, such that the value in the table can be interpreted as the change in percentage points of exports associated with a $\$ 1 / \mathrm{t} \mathrm{CO}_{2}$ tax, similar to other columns in the table.
} 
consistent with other formulations, although the estimate is higher and has a larger standard error although still statistically distinguishable from zero at a 1 percent level. For this model, the estimate suggests that a $\$ 10 / \mathrm{CO}_{2}$ tax was associated with a $6.7 \%$ increase in the value of exports from British Columbia’s agriculture sector.

Table 2 presents the results of a regression where commodity dummies are interacted with the carbon tax variable. The model is otherwise the same as in column 3 of Table $1{ }^{14}$ This pattern of interaction permits heterogeneity on a commodity-specific basis. It may be that different agricultural commodities responded differently to the introduction of the carbon tax and this formulation allows for this flexibility. Table 2 demonstrates that coefficient estimates for most commodities are of the same sign as for the aggregate agricultural commodity, and a number of commodities are estimated precisely. Only two commodities have signs that deviate from those in Table 1: live trees and other floriculture and vegetables. In the case of vegetables, the coefficient is nearly zero, and the standard error is large, suggesting no discernible effect. In the case of live trees and other floriculture, the value of exports does appear to have dropped somewhat with the introduction of the carbon price, although the point estimate does not allow us to reject a zero effect with a high degree of precision.

\subsection{Results for net exports}

The preceding analysis, focused on gross exports of agricultural commodities, suggests that the implementation of the carbon tax in both BC and Quebec was associated with an increased share of production destined for export. In this section, we repeat the previous analysis, but focus on net exports instead of gross exports.

\footnotetext{
${ }^{14}$ Note that not all commodities present in Table appear in Table 2, because not all commodities are sold in BC or Quebec while these provinces had carbon taxes implemented (and as such cannot be identified in the data).
} 
The main results are presented in Table 3, using the same format as Table 1 . In the first column, only the BC carbon tax is included, and the entire sample of commodities is used. Here, we find a positive, but statistically insignificant, effect of the carbon tax on net exports. The point estimate is notably larger than in Table 1, possibly suggesting that in addition to an increase in exports, the carbon tax was associated with a decline in imports. It is important not to draw too strong a conclusion from this value because of the large standard error. Similar conclusions, along with similarly imprecise estimates, are shown in columns 2 and 3 of the table, where the definition of the carbon tax and the set of commodities are varied. In the fourth column, we use the log-linear functional form, and arrive at negative point estimate. ${ }^{15}$ This estimate is measured very imprecisely, however. As above, we also interact the commodity dummies with the carbon tax variable, to estimate effects on a commodity level. ${ }^{16}$ In this case, we are not able to estimate any of the coefficients with statistical precision. If there is an effect of the carbon tax on net exports, our data do not allow us to measure it precisely.

\subsection{Discussion}

Our analysis suggests that gross exports as a percentage of output in the agricultural sector increased as a consequence of the carbon taxes in both BC and Quebec. The models control for changes in temperature, precipitation, international commodity prices, tariffs, and the cost of other inputs required to produce agricultural commodities. The effect we identify is statistically significant. Coefficients are small, but economically meaningful: for the agricultural sector as a whole, it suggests that at $\$ 20 / \mathrm{CO}_{2}$, the carbon tax has caused a roughly 1.4 percentage point increase in the amount of domestic agricultural production destined for exports. When we disaggregate the effect by commodity, we find the same positive sign for all

\footnotetext{
${ }^{15}$ The implementation actually uses the inverse hyperbolic sine function rather than the natural logarithm to address problems of negatives in the dependent variable. The interpretation is the same as in Table 1 above. ${ }^{16}$ Results are available from the authors upon request.
} 
commodities with the exception of floriculture and live trees and vegetables. For these latter two commodities, we find that the carbon tax is associated with a small, but statistically insignificant decline in gross exports as a percent of output.

This is an unusual finding: the natural expectation is that increases in environmental regulations and taxes should lead to a reduction in international competitiveness, and a decline in international exports. This seems to have motivated the exemptions granted to the greenhouse sector and the on-going review of the tax on the broader agricultural sector. We propose, but do not empirically test, two potential hypotheses to explain our findings.

First, as discussed in the context of the theoretical model, the introduction of a carbon tax is likely to reduce net exports from carbon-intensive sectors, but to increase net exports from other labour-intensive sectors. If agricultural production is a relatively labour-intensive sector, then increases in exports from this sector following the introduction of the tax are consistent with theory. Unambiguous classifications of economic sectors into carbon-intensive or labourintensive are not possible given the available data. Our numerical exercise suggests that on average the agricultural sector is less carbon-intensive than many other traded goods sectors such that there is a possibility that it would experience an increase in comparative advantage following introduction of the carbon tax.

Second, there exists a possibility that the introduction of the carbon tax helped to stimulate process innovations on $\mathrm{BC}$ farms, which more than offset the first-order impact of the carbon tax. The potential for this dynamic to occur was first raised by Porter and van der Linde (1995). Since then, there have been a number of empirical tests of the so-called "Porter Hypothesis", some of which document cases where more stringent environmental regulations create an 
advantage for regulated firms compared to unregulated firms in other jurisdictions (Ambec, Cohen, Elgie, \& Lanoie, 2011).

\section{Policies to Address Competitive Concerns of Carbon Taxes on Agriculture}

The preceding sections of the paper have examined the effect of the carbon tax on the international competitiveness of the agricultural sector. The analysis finds little evidence that the international competiveness of $\mathrm{BC}$ agricultural firms declined following implementation of the carbon tax. It does not however preclude the possibility that certain agricultural sub-sectors experienced declines in exports following the introduction of the tax (or that other economic sectors experience declines in international competitiveness related to the tax). In addition, it is possible that even if international exports were relatively unaffected by the tax, profits in agricultural firms declined. For the economic efficiency or distributional reasons, the BC government may be interested in mitigating any leakage associated with the tax. Recognizing that legitimate concerns may exist, it is important to consider the suite of available strategies available to address these worries. The literature raises several possibilities, which could each be targeted at certain sectors that were considered most negatively affected by a carbon tax: (1) sector exemptions, (2) lump-sum rebates, and (3) output-based rebates. ${ }^{17}$

\section{Exemptions}

When implemented elsewhere (notably in Europe), carbon taxes have often been accompanied with exemptions for certain sectors to shield them from the full impact of the carbon tax. Such exemptions have taken various forms, including complete exemptions such as Norway's exemption for the carbon tax on coal use in the cement industry (Ekins \& Speck, 1999), conditional exemptions such as the UK’s Climate Change Agreements and Levy (Martin,

\footnotetext{
${ }^{17}$ Border tax adjustments are also the subject of a substantial literature, but are not explored here.
} 
de Preux, \& Wagner, 2011) and reduced tax rates which exist for most manufacturers subject to European carbon taxes (Ekins \& Speck, 1999). While such exemptions are politically popular, most economists consider them to be economically harmful because they entail forgoing costeffective opportunities to reduce carbon emissions (so to achieve the same level of emission reductions, more costly activities need to be pursued). For example, Bohringer and Rutherford (1997) estimate that sector exemptions are an extremely costly way to preserve employment in the exempted sector, and Hoel (1996) shows that sector exemptions are inferior to other support mechanisms that government can use.

Conventional economic wisdom suggests that the number of policy instruments should be equal to the number of policy goals. In the context of BC's carbon tax, there appear to be at least two goals facing policy makers - (1) improving environmental performance, and (2) maintaining international competitiveness. In addition, policy-makers may have other goals, such as maintaining employment or firm profitability when the carbon tax is implemented. Trying to address all three of these goals with a single policy (carbon tax with exemptions) is sub-optimal, and compromises in the efficient achievement of all goals. Instead, economic theory suggests that individual policies should be used to address each policy goal.

\section{Lump-sum rebates}

Sectoral rebates are an alternative form of compensation for affected sectors. Rebates can be unconditional (lump-sum) or conditional. Lump-sum rebates are transfers from government to a firm's shareholders, and should not create economic incentives or disincentives (of course, raising funds to provide the rebates can distort economic activity). In the current context, they would be used to support firms’ profits during a transitory period when carbon taxation was applied, in a manner similar to the \$100 Climate Action Dividend which was provided to households when BC’s carbon tax was first implemented. Goulder, Hafstead, and Dworsky 
(2010) estimate that to preserve firm profits following implementation of a carbon tax, a lump sum transfer equivalent to about 15 percent of total carbon tax payments is adequate for energyintensive firms in the US. A 100 percent lump sum rebate substantially over-compensates industries. Despite this finding, a number of market-based climate policies do provide substantial lump-sum rebates for participating sectors. For example, the European Union's Emission Trading System uses a lump-sum allocation of emission permits to industrial facilities, similar to the allocation system in the US sulfur dioxide trading program. Importantly, a lump sum rebate is not tied directly to a firm's current carbon emissions or fossil fuel use (or any other current-year variable). Instead, a lump sum rebate could be distributed on a per-firm basis (similar to the climate action dividend, which distributed revenue on a per-person basis) or based on historic emissions. In this way, the rebate does not impact firm decisions, and functions purely as a transfer mechanism.

\section{Output-based rebates}

An alternative to lump-sum rebates are conditional rebates, in which rebates to a sector depend on a firm's performance. Fischer and Fox (2009) explore output-based rebates, where rebates to a firm are calculated based on a measure of physical or economic output. For example, a sector may receive a rebate which is some percentage of total carbon tax payments, and distribution of the rebate within firms in the sector might be according to shares of physical output (e.g., tonnes of corn produced). This structure provides the firm with two incentives: first, because of the carbon tax, each firm faces an incentive to reduce emissions, and second, because

firms receive a subsidy contingent on their share of sector output, each firm faces an incentive to increase output. This structure can help to mitigate some of the negative impacts of the tax on “competitiveness.” Simulations suggest that this type of rebating can be effective (Fischer \& Fox, 2007). 


\section{Conclusions}

Although the design of the carbon tax adopted in BC in 2008 appears to conform very closely to "best-practice,” there remain concerns about implementation. Most important, the carbon tax is unilateral and may provide incentives for carbon-intensive firms to shift production to other jurisdictions to avoid paying the tax. Partly in response to this concern, in its 2012 budget, the BC government offered a temporary (1-year) exemption to the greenhouse sector, which reported problems with international competitiveness as a result of the tax.

Our aim in this paper is to evaluate the impact of the BC carbon tax on the international competitiveness of the agricultural sector. We demonstrated that amongst highly-traded sectors in BC, the agricultural sector has a fossil fuel intensity that is about average. Thus the model does not give an unambiguous prediction for whether the carbon tax would likely expand or contract net exports from the sector. Next, we estimated the impact of the carbon tax on agricultural exports using a panel data set, covering production, imports, and exports of a number of agricultural commodities in each province in Canada over the 22-year period from 1990 to 2011. We control for time-variant factors that are similar for all provinces (world commodity prices, national tariffs, costs and environmental policies in other countries), time-invariant factors that are specific to each province (comparative advantage), as well as weather. Our results suggest that the carbon tax is associated with an increase in gross exports that is statistically different from zero. In particular, our preferred model suggests that agricultural exports as a fraction of total output increased by about 1.5 percentage points following introduction of the $\$ 20 / \mathrm{CO}_{2}$ tax. We were unable to find any precisely measured impact of the carbon tax on net exports. Examining heterogeneous responses across commodities, we do find 
a small, statistically insignificant effect on floriculture and vegetable exports. In sum, these results suggest that it is unlikely that the carbon tax caused a large negative impact on the international competitiveness of the agricultural sector. As a result, the exemptions from the carbon tax for the greenhouse sector, which were justified primarily based on concerns over international competitiveness, are likely unnecessary.

To our knowledge, this analysis is the first to estimate the ex post effect of the BC carbon tax on firm performance. We believe that it is a useful initial study in a field that deserves more attention. In particular, this research was based on aggregate data. Using firm-level microdata, it would likely be possible to generate more precise estimates of the impact of the tax on firm performance, and to test other hypotheses relating to the causal impact of the tax. We believe that this would be a fruitful avenue for future research. 


\section{Works Cited}

Ambec, S., Cohen, M., Elgie, S., \& Lanoie, P. (2011). The Porter Hypothesis at 20: Can environmental regulation enhance innovation and competitiveness? Working paper, Resources for the Future.

BC Budget Consultation. (2012). Retrieved September 2012, from http://www.leg.bc.ca/cmt/39thparl/session-4/fgs/hansard/hansindx/FGSNDX-3-4c.htm\#mh194

BC Budget Speech. (2012, March). Retrieved September 2012, from http://www.bcbudget.gov.bc.ca/2012/speech/2012_Budget_Speech.pdf

BC Ministry of Agriculture. (2012). News Release: \$7.6M Carbon Tax Relief Supports B.C.'s Greenhouse Jobs. Retrieved September 2012, from http://www2.news.gov.bc.ca/news_releases_2009-

2013/2012AGRI0008-000405.htm

BC Ministry of Finance. (2012). Budget and Fiscal Plan 2012/13. Retrieved July 2012, from www.bcbudget.gov.bc.ca/2012/bfp/2012_Budget_Fiscal_Plan.pdf

BC Ministry of Finance. (2011). How the Carbon Tax Works. Retrieved July 2012, from www.fin.gov.ba.ca/tbs/tp/climate/A4.htm

Bohringer, C., \& Rutherford, T. (1997). Carbon taxes with exemptions in an open economy: A general equilibrium analysis of the German tax initiative. Journal of Environmental Economics and Management, 32 (2), 189-203.

Carter, C., Krissoff, B. and Zwane, A. P. (2006). Can Country-of-Origin Labeling Succeed as a Marketing Tool for Produce? Lessons from Three Case Studies. Canadian Journal of Agricultural Economics, 54: 513-530.

Copeland, B., \& Taylor, M. (2004). Trade, growth, and the environment. Journal of Economic Literature, 42, 7-71.

Ekins, P., \& Speck, S. (1999). Competitiveness and Exemptions from Environmental Taxes in Europe. Environmental and Resource Economics 13: 369-396.

Felder, S., \& Rutherford, T. (1993). Unilateral CO2 reductions and carbon leakage: The consequences of international trade in oil and basic materials. Journal of Environmental Economics and Management , 25 (2), 162-176.

Fischer, C., \& Fox, A. (2007). Output-based allocations of emissions permits for mitigating tax and trade interactions. Land Economics, 83 (4), 575-599.

Fischer, C., \& Newell, R. (2008). Environmental and technology policies for climate mitigation. Journal of Environmental Economics and Management , 55 (2), 142-162.

Fisher, C., \& Fox, A. K. (2009). Combining Rebates with Carbon Taxes. Ressources for the Future, Discussion paper. 
Goulder, L. (1995). Environmental taxation and the double dividend: A reader's guide. International Tax and Public Finance, 2 (2), 157-183.

Goulder, L., Hafstead, M., \& Dworsky, M. (2010). Impacts of alternative emissions allowance allocation methods under a federal cap-and-trade program. Journal of Environmental Economics and Management , 60 (3), 161-181.

Goulder, L., Parry, I., \& Burtraw, D. (1997). Revenue-raising versus other approaches to environmental protection: The critical significance of pre-existing tax distortions. RAND Journal of Economics, 28 (4), 708-731.

Harrison, K. (2012). A Tale of Two Taxes: The Fate of Environmental Tax Reform in Canada. Review of Policy Research, No. 3.

Hoel, M. (1996). Should a carbon tax be differentiated across sectors? Journal of Public Economics , 59 (1), 17-32.

Jaffe, A. B., Peterson, S. R., Portney, P. R., \& Stavins, R. N. (1995). Environmental Regulation and the Competitiveness of U.S. Manufacturing: What Does theEvidence Tell Us? Journal of Economic Literature, Vol. 33, No. 1 pp 132-163.

Jaffe, A., Peterson, S., Portney, P., \& Stavins, R. (1995). Environmental regulation and the competitiveness of US manufacturing. Journal of Economic Literature , 33 (1), 132-163.

Kellenberg, D. (2009). An empirical investigation of the pollution haven effect with strategic environment and trade policy. Journal of International Economics , 78, 242-255.

Levinson, A., \& Taylor, M. (2008). Unmasking the pollution haven effect. International Economic Review, 49 (1), 223-254.

Martin, R., de Preux, L. B., \& Wagner, U. J. (2011). The Impacts of the Climate Change Levy on Manufacturing: Evidence from Microdata. NBER Working Paper No. 17446.

Porter, M., \& van der Linde, C. (1995). Towards a new conception of the environment-competitiveness relationship. Journal of Economic Perspectives, 9 (4), 97-118.

Stavins, R. (1995). Transaction costs and tradable permits. Journal of Environmental Economics and Management, 29 (2), 133-148. 


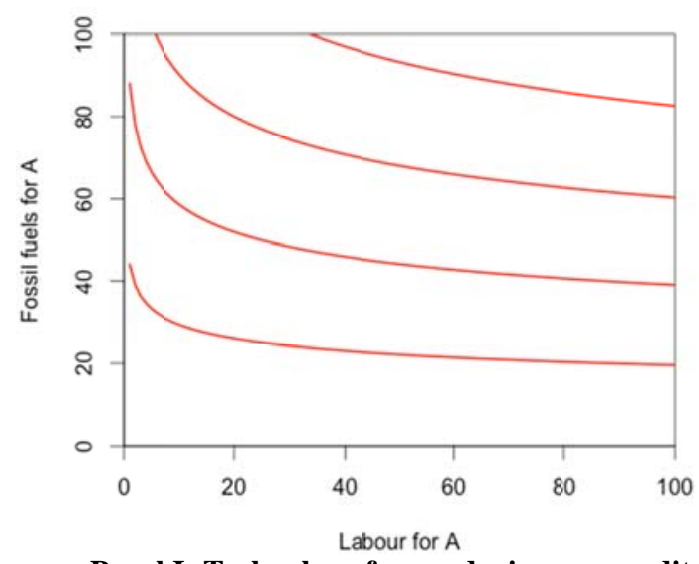

Panel I: Technology for producing commodity A

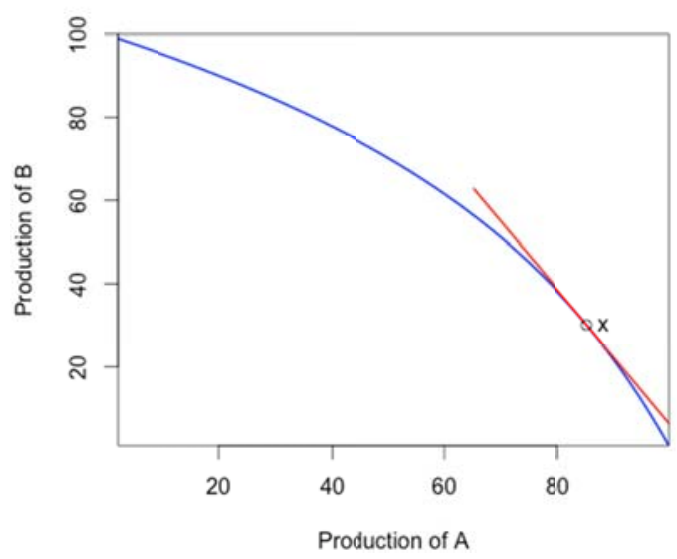

Panel III: Production possibility frontier

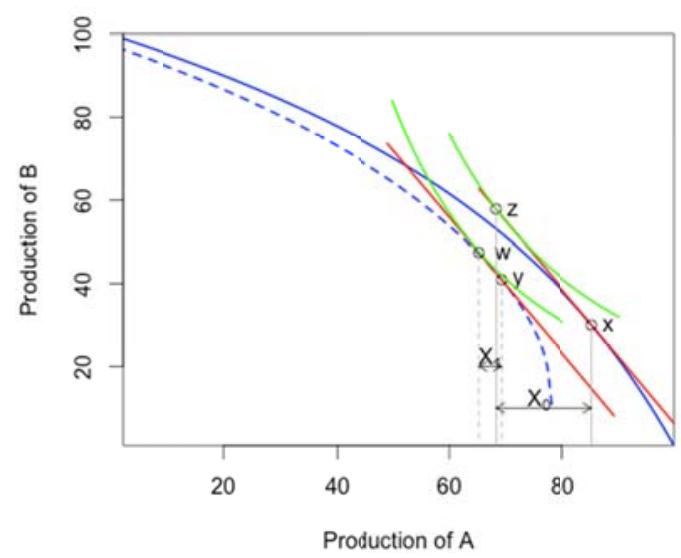

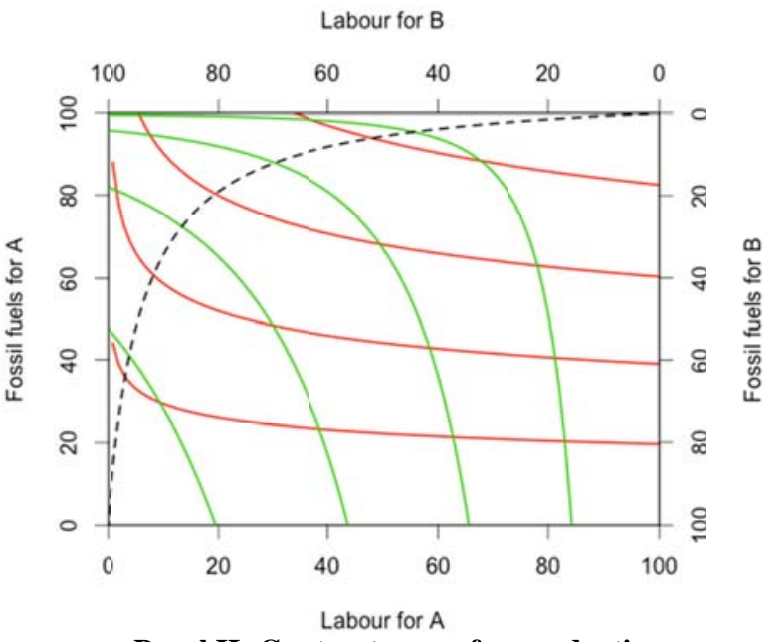

Panel II: Contract curve for production

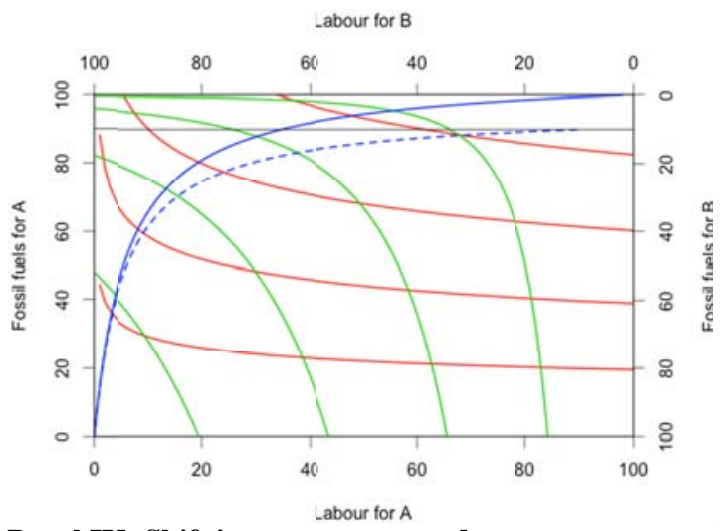

Panel IV: Shift in contract curve due to tax

Panel V: A shift in the production possibility frontier

Figure 1: Five Panel Representation Depicting the Consequences of Environmental Regulation on International Trade 


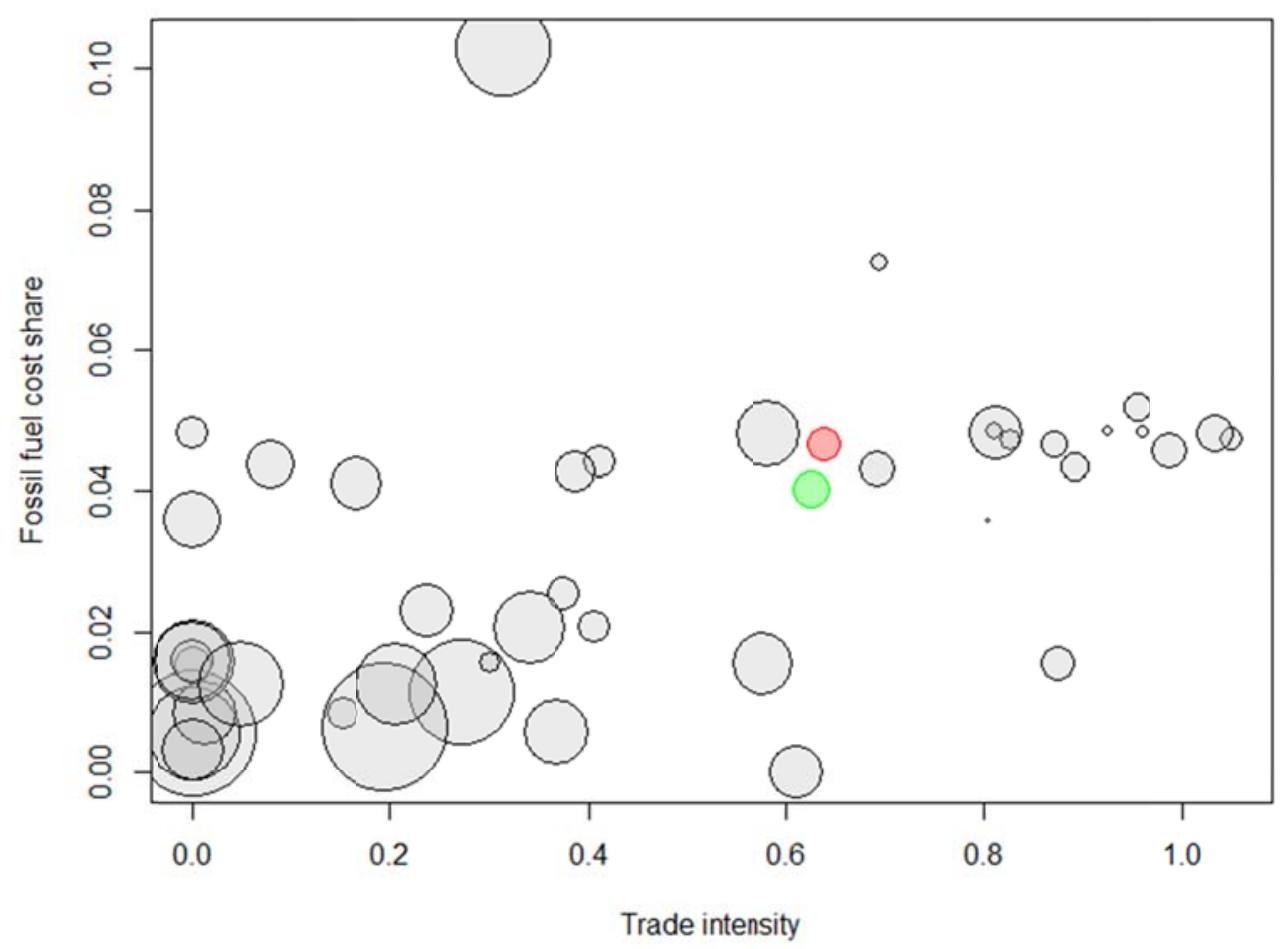

Figure 2: Trade intensity and fossil fuel cost share for BC commodities, 2007. Area of circles is proportional to total domestic output of commodities in 2007. The coloured circles correspond to agricultural products. The red circle represents "Fruit, vegetables, and other food products and feeds", while the green circle represents "Meat, fish, and dairy products.” 
Table 1: Effect of the BC Carbon Tax on Gross Exports

\begin{tabular}{|c|c|c|c|c|}
\hline & (1) & (2) & (3) & (4) \\
\hline Carbon tax - & $0.335^{*}$ & 0.069 & $0.414 *$ & $0.674^{*}$ \\
\hline$\$ / \mathrm{tCO}_{2} \mathrm{e}$ & $(0.144)$ & $(0.152)$ & $(0.146)$ & $(0.222)$ \\
\hline $\mathrm{R}^{2}$ & 0.87 & 0.84 & 0.87 & 0.89 \\
\hline $\mathrm{N}$ & 1943 & 1281 & 1943 & 1943 \\
\hline $\begin{array}{l}\text { Carbon tax } \\
\text { variable }\end{array}$ & $B C$ & $\mathrm{BC}$ & $\begin{array}{c}\mathrm{BC}+ \\
\text { Quebec }\end{array}$ & $B C$ \\
\hline Sample & All & $\begin{array}{c}\text { Exclude } \\
\text { single-desk } \\
\text { marketed }\end{array}$ & All & All \\
\hline Functional form & Linear & Linear & Linear & Log-linear \\
\hline
\end{tabular}


Table 2: Commodity-specific Effects of Carbon Tax on Gross Exports

\begin{tabular}{ll}
\hline Interaction & Estimate \\
\hline Carbon tax*Cattle & 0.70 \\
& $(0.39)$ \\
Carbon tax*Swine & $7.24^{*}$ \\
& $(2.74)$ \\
Carbon tax*Sheep and goats & 0.49 \\
& $(0.39)$ \\
Carbon tax*Honey & 0.23 \\
& $(0.39)$ \\
Carbon tax*Live trees and floraculture & -0.52 \\
& $(0.39)$ \\
Carbon tax*Vegetables & -0.04 \\
& $(0.39)$ \\
Carbon tax*Fruit & 0.75 \\
& $(0.42)$ \\
Carbon tax*Wheat & $1.29 *$ \\
& $(0.55)$ \\
Carbon tax*Barley & 0.18 \\
& $(0.47)$ \\
Carbon tax*Oats & $1.16^{*}$ \\
Carbon tax*Canola & $(0.48)$ \\
& 0.39 \\
Clustered standard errors in parentheses (provinces). & $(0.43)$ \\
* - indicates significant at the 5 percent level. \\
All models include time-commodity and provincial fixed effects as well as a full set of weather variables.
\end{tabular}


Table 3: Effect of the BC Carbon Tax on Net Exports

\begin{tabular}{|c|c|c|c|c|}
\hline & (1) & $(2)$ & (3) & (4) \\
\hline Estimate & 1.717 & 3.934 & 2.118 & -0.510 \\
\hline & $(1.682)$ & $(2.480)$ & $(1.721)$ & (2.293) \\
\hline $\mathrm{R}^{2}$ & 0.76 & 0.76 & 0.76 & 0.89 \\
\hline $\mathrm{N}$ & 1943 & 1281 & 1943 & 1943 \\
\hline Carbon tax variable & $B C$ & $\mathrm{BC}$ & $\begin{array}{c}\text { BC + } \\
\text { Quebec }\end{array}$ & $B C$ \\
\hline Sample & All & $\begin{array}{c}\text { Non } \\
\text { single- } \\
\text { desk } \\
\text { marketed }\end{array}$ & All & All \\
\hline Functional form & Linear & Linear & Linear & Log-linear \\
\hline
\end{tabular}




\section{Appendix A}

Table A1: Concordance for agricultural commodities

\begin{tabular}{|c|c|}
\hline Statistics Canada commodity (Table 002-0001) & Industry Canada commodity (HS Code) \\
\hline Wheat & HS 1001 - WHEAT \\
\hline Durum Wheat & HS 1001 - WHEAT \\
\hline $\begin{array}{l}\text { Wheat, excluding durum, marketing board } \\
\text { payments }\end{array}$ & HS 1001 - WHEAT \\
\hline Durum wheat, marketing board payments & HS 1001 - WHEAT \\
\hline Oats & HS $1004-$ OATS \\
\hline Oats, Canada Wheat Board payments & HS 1004 - OATS \\
\hline Barley & HS 1003 - BARLEY \\
\hline Barley, Canada What Board payments & HS 1003 - BARLEY \\
\hline Rye & HS $1002-$ RYE \\
\hline Flaxseed & HS 120400 - LINSEED \\
\hline Canola, rapeseed & $\begin{array}{l}\text { HS } 1205 \text { - RAPE OR COLZA SEEDS (WHETHER OR } \\
\text { NOT BROKEN) }\end{array}$ \\
\hline Soybeans & $\begin{array}{l}\text { HS } 1201 \text { - SOYA BEANS, WHETHER OR NOT } \\
\text { BROKEN }\end{array}$ \\
\hline Corn & HS 1005 - CORN \\
\hline Greenhouse vegetables & $\begin{array}{l}\text { HS } 07 \text { - Edible Vegetables and Certain Roots and } \\
\text { Tubers }\end{array}$ \\
\hline Potatoes & $\begin{array}{l}\text { HS } 07 \text { - Edible Vegetables and Certain Roots and } \\
\text { Tubers }\end{array}$ \\
\hline Vegetables & $\begin{array}{l}\text { HS } 07 \text { - Edible Vegetables and Certain Roots and } \\
\text { Tubers }\end{array}$ \\
\hline Total tree fruits & HS 08 - Edible Fruits and Nuts \\
\hline Apples & HS 08 - Edible Fruits and Nuts \\
\hline Other tree fruits & HS 08 - Edible Fruits and Nuts \\
\hline Total small fruits & HS 08 - Edible Fruits and Nuts \\
\hline Blueberries & HS 08 - Edible Fruits and Nuts \\
\hline Strawberries & HS 08 - Edible Fruits and Nuts \\
\hline Grapes & HS 08 - Edible Fruits and Nuts \\
\hline Other berries and grapes & HS 08 - Edible Fruits and Nuts \\
\hline Floriculture & $\begin{array}{l}\text { HS } 06 \text { - Live Trees and Other Plants (Incl. Cut } \\
\text { Flowers and Ornamental Foliage) }\end{array}$ \\
\hline Nursery & $\begin{array}{l}\text { HS } 06 \text { - Live Trees and Other Plants (Incl. Cut } \\
\text { Flowers and Ornamental Foliage) }\end{array}$ \\
\hline Sod & $\begin{array}{l}\text { HS } 06 \text { - Live Trees and Other Plants (Incl. Cut } \\
\text { Flowers and Ornamental Foliage) }\end{array}$ \\
\hline Cattle & HS $0102 \& 0201 \& 0202-$ CATTLE \\
\hline Calves & HS 0102 \& $0201 \& 0202-$ CATTLE \\
\hline Hogs & HS 0103 \& 0203 - SWINE \\
\hline Sheep & HS 0104 \& HSO204 SHEEP AND GOATS \\
\hline Lambs & HS 0104 \& HSO204 SHEEP AND GOATS \\
\hline Honey & HS 0409 - HONEY, NATURAL \\
\hline
\end{tabular}


Table A2: Climate data and province concordance

\begin{tabular}{|l|l|}
\hline Province & Climate region \\
\hline Newfoundland and Labrador & Atlantic Canada \\
\hline Prince Edward Island & Atlantic Canada \\
\hline Nova Scotia & Atlantic Canada \\
\hline New Brunswick & Atlantic Canada \\
\hline Quebec & Great Lakes/St. Lawrence \\
\hline Ontario & Great Lakes/St. Lawrence \\
\hline Manitoba & Prairies \\
\hline Saskatchewan & Prairies \\
\hline Alberta & Prairies \\
\hline British Columbia & South BC Mountains \\
\hline
\end{tabular}

